\title{
鋳鉄及び軟鋼に対する水・グリコール作動液の防食性*
}

\author{
金森英夫**, 飯野光明**, 辻川茂男*** \\ ** 出光興産株式会社営業研究所 \\ *** 東京大学工学部金属材料学科
}

\section{Corrosion Inhibition of Aqueous Glycol Solution to Cast Iron and Mild Steel}

\author{
Hideo Kanamori**, Mituaki Iino** and Shigeo Tsujikawa*** \\ ** Lubricants Research Laboratories, Idemitu Kosan Co., Lid \\ *** Department of Materials Science, Faculty of Engineering, The University of Tokyo
}

\begin{abstract}
Cast iron and carbon steel become passive in caustic hydraulic luburicants of aqueous glycol solution with help of slightly dissolved oxygen from the air. They have performed well over 10 years in practical uses, but have some service experiences of crevice corrosion in the environments, as observed for stainless steels in neutral solutions. In this report causes of crevice corrosion are examined in terms of $\mathrm{pH}$ and critical potentials. $\mathrm{pH}$ values of $\mathrm{A} \sim \mathrm{B}$ measured for solutions in practical cases of crevice corrosion were higher than depassivation $\mathrm{pH}\left(\mathrm{pH}_{\mathrm{d}}\right)$, which shows that the $\mathrm{pH}$ values are not responsible to the corrosion. Spontaneous electrode potential $\left(E_{\mathrm{SP}}\right)$ for the steels passivated in the solution was determined to be about $-0.15 \mathrm{~V}$ vs. SCE. Critical potentials, $V_{\mathrm{CREv}}$, above which crevice corrosion initiates and continues to grow over $20 \mu \mathrm{m}$ in depth were measured as a function of $\mathrm{Cl}^{-}$content of the solution and found to coincide to repassivation potential, $E_{\mathrm{R}}{ }^{*}, \mathrm{CREV}$ for crevice corrosion shallower than $20 \mu \mathrm{m}$. $\mathrm{Cl}^{-}$more than $10 \mathrm{ppm}$ makes $V_{\mathrm{CREV}}$ or $E_{\mathrm{R}}{ }^{*}$, CREv less noble than $E_{\mathrm{SP}}$ and might lead to the crevice corrosion in the cases studied. To control $\mathrm{Cl}^{-}$content blow $10 \mathrm{ppm}$ is an effective way to avoid the crevice corrosion.
\end{abstract}

Key words: corrosion inhibition, passive, crevice corrosion, cast iron, mild steel, aqueous glycol solution, $\mathrm{pH}_{\mathrm{d}}$ : depassivation $\mathrm{pH}, E_{\mathrm{SP}}$ : spontaneous electrode potential, $V_{\mathrm{CREv}}$ : critical potential above which crevice corrosion initiates, $E_{\mathrm{R}, \mathrm{CREv}}$ : repassivation potential for crevice corrosion $\mathrm{Cl}^{-}$content

\section{1.はじめに}

液圧駆動機械の動力伝達媒体である水・グリコール系 作動液 (以下, WG 作動液といら) は, 従来から使用さ れている鉱油系に比べ難燃性のため, 防火対策が強化さ れる工場設備の動向に合致し,使用実績が増加している。

WG 作動液は, 鉱油系作動油に類似の各種特性 (粘性,

* 第 5 回装置材料の Performance 研究会 (東京), 第 33 回腐食防食討論会 (沖縄) にて発表

** 干 299-01 千葉帠市原市姉崎海岸 24 の 4 24-4, Anesaki Kaigan, Ichihara-City, Chiba, 299-01 Japan)

*** 干113 東京都文京区本郷 7-3-1 (7-3-1, Hongo, Bunkyo-ku, Tokyo, 113 Japan)
潤滑性，防食性など）を有するが，水溶液であるため， 装置設計や保守管理には, 鉱油系とは異なる対応が必要 な場合がある。防食への対応もとのひとつである。

防食の対象となる装置材料は, おもに鋳鉄や炭素鋼 で, WG 作動液はとれらの金属光沢を 10 年以上にわた り維持する能力を持つ。すきま腐食は通常にも認められ るが，それらのほとんどは進行性のものではない。しか し進行性の腐食に転じ, 大さな損傷をもたらす場合があ る。

たとえば,鋳鉄フランジの O-リングパッキンに接触す る部分を起点に, 鋳鉄地肌が著しく侵食されていくとい ら事例があったといら。このような腐食損傷は通常は起 
Table 1 Summary of case studies. $E_{\mathrm{SP}}$ is spontaneous electrode potential measured for carbon steel wall of service tanks. $\mathrm{Cl}^{-}$content, $\mathrm{pH}$ and conductivity of WG Solution were shown with occurrence of crevice corrosion.

\begin{tabular}{|c|c|c|c|c|c|c|}
\hline & \multirow{2}{*}{$\begin{array}{l}{\mathrm{C} 1^{-}} \\
(\mathrm{ppm})\end{array}$} & \multicolumn{2}{|c|}{$\mathrm{pH}$} & \multirow{2}{*}{$\begin{array}{l}\text { Conduc- } \\
\text { tivity } \\
(\mu \mathrm{S} / \mathrm{cm})\end{array}$} & \multirow{2}{*}{$\begin{array}{c}E_{s p} \\
\left(\begin{array}{l}V \\
\text { vs. }\end{array}\right. \\
\text { SCE })\end{array}$} & \multirow{2}{*}{$\begin{array}{l}\text { Crevice } \\
\text { Corrosion }\end{array}$} \\
\hline & & $20^{\circ} \mathrm{C}$ & $60^{\circ} \mathrm{C}$ & & & \\
\hline Case & $5>$ & 10.1 & 9.6 & 960 & -0.15 & no \\
\hline & $5>$ & 10.0 & 9.5 & 980 & -0.13 & no \\
\hline & 5 & 10.1 & 9.6 & 970 & -0.15 & no \\
\hline & 5 & 9.6 & 9.1 & 990 & - & no \\
\hline & 8 & 9.5 & 9.0 & 1110 & - & no \\
\hline & 20 & 9.4 & $8.9^{\circ}$ & 1620 & - & yes \\
\hline & 32 & 9.7 & 9.2 & 1770 & - & yes \\
\hline & 22 & 9.5 & 9.0 & 1680 & - & yes \\
\hline & 16 & 9.4 & 8.9 & 1900 & - & yes \\
\hline
\end{tabular}

こらないが，何らかの条件が成立した時に発生するもの と考光られる。筆者らの調査例を Table 1 に示した。こ れは通常に問題なく使用された WG 液 (Case 1〜5) と, すきま腐食を起こした WG 使用液 (Case 6〜9) の性状 をまとめたものである。すきま腐食を起こした液は $\mathrm{pH}$ 值が新液に比べ，0.3 0.7 ほど低下し，また導電率が上 昇し, $\mathrm{Cl}^{-}$濃度が $16 \sim 32 \mathrm{ppm}$ と高いことがわかる。また $40 \sim 60^{\circ} \mathrm{C}$ の温度域で使用されていることがわかった。

十分にアルカリ性の水環境では大気酸素の共存下に鉄 も自己不動態化することがよく知られている1)。本報で は, この不動態からの離脱をもたらすと考兄られる, $\mathrm{pH}$ 低下または $\mathrm{Cl}^{-}$による局部腐食の双方について, 前者は 脱不動態化 $\mathrm{pH}, \mathrm{pH}_{\mathrm{d}}$ 概念を, 後者はステンレス鋼 ${ }^{2), 3)}$ やチタン4)で確立されているすきま再不動態化電位 $E_{\mathrm{R}, \mathrm{CREV}}$ 概念を適用して検討した。

\section{2. 実験方法}

\section{1 試験液の組成と性状}

試験液である WG 液 A は一般的な WG 作動液とし ての諸特性を満足すべく, 通常用いる化学基材により,

Table 2 に示す組成に調合した。その性状を Table 3 に 示す。WG 液 $\mathrm{A}$ が $\mathrm{pH}$ 值 10 を示すのは油性・防錆添 加剂であるカリウム石けんとアミン系気化性防錆剂によ る。脱不動態化 $\mathrm{pH}$ 等を測定するための $\mathrm{pH}$ 調整は現 場での実際にあわせてこの気化性防錆剂, N,N-diethylethanolamine (以下 DEEA と略記), とカリウム石けん の成分である Caprylic acid の添加量を変えることによ り行った。また $\mathrm{Cl}^{-}$濃度の調整は $\mathrm{NaCl}$ 特級試薬を用 い, 実験はすべて液温度 $60^{\circ} \mathrm{C}$ のもとで行った。

\section{2 試 験 片}

Table 4 に示す化学成分の鋳鉄と軟鋼とのそれぞれに ついて, Fig. 1 (a) に示す金属/NBR-すきま試験片, 及 び (b) 自由表面試験片を作成し, 実験に用いた。
Table 2 Components of WG Solution A

\begin{tabular}{|l|l|c|}
\hline \multicolumn{2}{|c|}{ Component } & Weight $\%$ \\
\hline Hater & Pure water $(1 \sim 5 \mu \mathrm{S} / \mathrm{cm})$ & 40 \\
\hline Pour Point Depressants & Mono-and dialkylene glycols & 36 \\
\hline Viscosity Improver & Polyalkylene glycol & 15 \\
\hline Orlinese Agents & Potassium oleate,caprilate & 6 \\
\hline Vapor Phase Inhibitor & N.N-diethylethanolamine & 2.7 \\
\hline Copper Deactivater, Anti-foam Agent, Dyes & 0.3 \\
\hline
\end{tabular}

Table 3 Properties of WG Solution A

\begin{tabular}{|l|r|}
\hline \multicolumn{1}{|c|}{ Item } & Value \\
\hline Specific Gravity at $15 / 4^{\circ} \mathrm{C}$ & 1.0428 \\
\hline Viscosity at $40^{\circ} \mathrm{C}$ (cSt.) & 45.7 \\
\hline Pour Point $\left({ }^{\circ} \mathrm{C}\right)$ & -40 \\
\hline Reserve Alkalinity (mgKOH/g) & 20.1 \\
\hline Foaming Tendency at $24^{\circ} \mathrm{C}, \mathrm{JIS} \mathrm{K2518}$ & $280-0$ \\
\hline Conductivity at $20^{\circ} \mathrm{C}(\mu \mathrm{S} / \mathrm{cm})$ & 980 \\
\hline pH at $20^{\circ} \mathrm{C}$ & 10.0 \\
\hline pH at $60^{\circ} \mathrm{C}$ & 9.5 \\
\hline
\end{tabular}

Table 4 Chemical compositions in weight $\%$ of ductile cast iron and mild steel used.

(weight \%)

\begin{tabular}{|l|c|c|c|c|c|}
\hline & $\mathrm{C}$ & $\mathrm{Si}$ & $\mathrm{Mn}$ & $\mathrm{P}$ & $\mathrm{S}$ \\
\hline Mild Steel & 0.01 & 0.03 & 0.22 & 0.017 & 0.014 \\
\hline Ductile Cast Iron & 3.61 & 3.12 & 0.29 & 0.042 & 0.008 \\
\hline
\end{tabular}

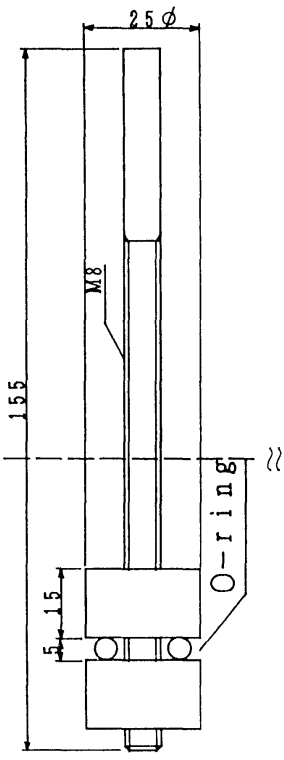

(a)

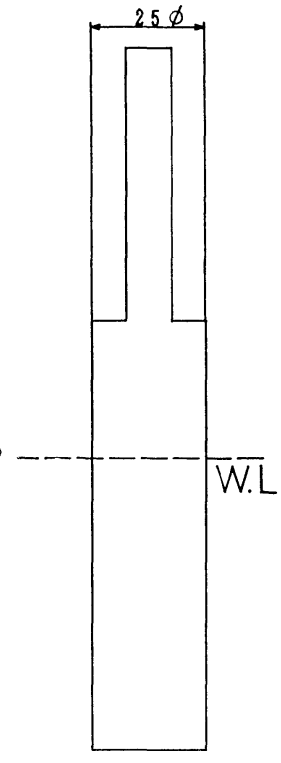

(b)
Fig. 1 Test specimen.

(a) The crevice assembly formed by a bolt, two nuts made of cast iron or mild steel and O-ring of NBR.

(b) The free surface specimen of $25 \mathrm{~mm}$ in diameter. 


\subsection{1すきま試験片の組み立て}

試験片は, ボルト (M 8, 長さ $155 \mathrm{~mm})$ 飞 NBR O-リ ング（日本バルカー社製 P-16）をはさんだ二つの丸ナッ 卜 (值径 $25 \mathrm{~mm}$, 高さ $15 \mathrm{~mm}$ ) を Fig. 1 (a) のように取 り付け,ナットを指で堅く締め,試験液中に図中の W.L. まで浸漬した。なお、ボルトとナットは加工後防錆油を 塗布して保存して扣き,測定を行ら時, ボルトとナットは ヘキサン・メタノール洗浄を、また O-リングは水洗浄 を行った。洗浄した試験片ナットすきま形成面は \#80\#1200 の SiC 研磨紙を用いて湿式にて研磨し,ナットを

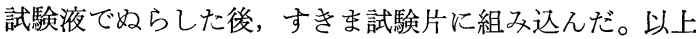
の洗浄から組み立てまでに要する時間は約 15 分とし た。

\subsection{2 自由表面試験片}

Fig. 1 (b) 飞示す円柱型 (直径 $25 \mathrm{~mm}$ ) 試験片は, 旋盤 による切削加工の際，切削油をかけないドライ方式によ り，仕上げ面粗さを $R_{\max }=5 \sim 10 \mu \mathrm{m}$ となるよう調製 した。作成後 15 分以内に水洗浄を行い，直ちに試験液 中に浸漬した。浸漬部分の長さは約 $50 \mathrm{~mm}$ とした。

\section{3 分極実験装置}

内容積が $1.2 l$ のガラス製容器に $1.0 l$ の試験液を入 れ，緩密閉のふたを設けそそれにゴム栓を介して試験片 を固定した。通常は外気と緩密閉の状態に保つが，必要 に応じ $\mathrm{N}_{2}$, なたは $\mathrm{O}_{2}$ を通気した。照合電極には室温の

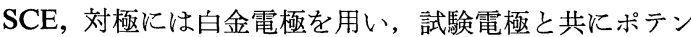
ショスタットに接続した。

\section{4 すきま腐食発生下限界電位 $V_{\mathrm{CREV}}$ の測定}

すきま試験片を試験液中に 30 分間自然浸漬した後, 各種の電位・時間条件飞保持する定電位分極実験を行っ た。実験後すきま腐食による侵食部分の最大深さを， 3.7 に後述する方法で測定し，これが $20 \mu \mathrm{m}$ をこえる進 行性すきま腐食を発生する下限界電位 $V_{\mathrm{CREV}}$ をるとめ た。

\section{5 すきま再不動態化電位 $\boldsymbol{E}_{\mathrm{R}, \mathrm{CREV}}$ の測定}

すきま試験片を試験液中に 30 分間自然浸漬した後, 自動化測定法 $\left.{ }^{5}\right)$ 準じ， $\mathrm{E}_{\mathrm{R}, \mathrm{CREV}}$ を測定した。

\section{6 動電位法孔食電位 $V_{C, 10}^{\prime}$ の測定}

自由表面試験片について，電位を貴方向に掃引する動 電位法により孔食電位を測定した。掃引は貴方向に 10 $\mathrm{mV} / 10 \mathrm{~min}$ で段階的に行い, 電流密度が $10 \mu \mathrm{A} / \mathrm{cm}^{2}$ に 達した電位により, 動電位法孔食電位, $\mathrm{V}^{\prime}{ }_{\mathrm{C}, 10}$ を決定し た。

\section{7 侵食深さの測定}

侵食深さは, 腐食生成物の除去が困難であったため, チタン4) で行った方法と同様, ビッカース硬度計圧痕凹 みを基準に用いる研磨法により測定した。

すなわち，すきま面の非侵食部分に圧痕凹みをつけ，そ
の深さ (P 1) を光学顕微鏡で測定しておく。次に侵食が 顕微鏡観察で認められなくなるまですきま面を研磨して 行き，侵食が全く認められなくなった時の圧痕凹み深さ (P 2) を測定する。侵食深さは，研磨による除去分 (P 1P 2) として求めた。

\section{8 自然電位, $E_{\mathrm{SP}}$ の測定}

$\mathrm{N}_{2}$ 脱気した $60^{\circ} \mathrm{C}$ の試験液中に自由表面試験片を浸 漬し, $-1.4 \mathrm{~V}$ に 30 分保持後開路し同時に, $\mathrm{O}_{2}$ を通気 する， $\mathrm{N}_{2}$ を通気する，あるいは容器を緩密閉のまま脱 気は行わない，の三つの場合について電極電位の時間变 化を測定した。それぞれの場合について，十分時間経過 後に到達する自然電位 $E_{\mathrm{SP}^{\prime}}$ を測定した。この時，全面 が不動態であることの確認ができる場合，その值を $E_{\mathrm{SP}}$ とした。

\section{9 脱不動態化 pH の測定}

Table 2 に示すWG 液 A の成分で DEEA だけを配 合しない試験液を調合する。この液の $\mathrm{pH}$ は 7.9 であ る。この試験液に自由表面試験片を浸漬し，マグネット スターラーで攪拌しながら，脱気は行わずに開路状態で の電極電位の時間変化をみた。電極電位の時間変化率 $(\Delta E / \Delta t)$ が $|10| \mathrm{mV} / \mathrm{h}$ 以下となり電極電位がほぼ定常に 達したと見なされた時の值を $E_{\mathrm{SP}^{\prime}}$ として測定した。以 降は, DEEAを試験液 $\mathrm{pH}$ が 0.1 上昇するまで約 $2 \mathrm{~m} l$ 添加し上述の $E_{\mathrm{SP}^{\prime}}$ を測定する，という操作を $0.1 \mathrm{pH}$ 上 昇ごとに繰り返した。次に Caprylic acid を上述と同様 の操作で $\mathrm{pH}$ 值 9.5 の WG 液 A 飞添加して, $\mathrm{pH}$ を 下げて行く時の電極電位 $E_{\mathrm{SP}^{\prime}}$ を測定した。以上の測定 はすべて $60^{\circ} \mathrm{C} て ゙$ 行った。

\section{3. 実験結果と考察}

\section{1 自然電位に及ぼす液 $\mathbf{p H}$ の影響}

$\mathrm{pH}$ を $9.5\left(\mathrm{pH} 10.0\right.$ at $\left.20^{\circ} \mathrm{C}\right)$ 記調整した $60^{\circ} \mathrm{C}$ のWG 液 $\mathrm{A}$ 中に浸漬した鋳鉄及び軟鋼の自由表面試験片につ いて，自然電位の時間変化を測定した結果を Fig. 2 亿示 す。鋳鉄, 軟鋼とも $\mathrm{O}_{2}$ 通気により自然電位が貴化する。 この時の電位は $24 \mathrm{~h}$ 経過後にほぼ定常に達し, $-0.18 \mathrm{~V}$ であった。通気を行わない緩密閉の場合の電位も時間的 には遅れるが単調に貴化し続け, $168 \mathrm{~h}$ 経過後には同じ 值に達した。以上の試験後に試験片はいずれも金属光沢 を示し, 上述の $-0.18 \mathrm{~V}$ は不動態化鋼の 自 然電位, $E_{\mathrm{SP}}$ と久なせる。しかし $\mathrm{N}_{2}$ を通気して脱気した場合は $-0.80 \mathrm{~V}$ といら非常に卑な電位にとどをった。

$60^{\circ} \mathrm{C}$ での $\mathrm{pH}$ 值が 7.9, 8.9, 9.5 あるいは 10.6 であ る脱気しないWG 液 A 中に扔いて, 自由表面試験片が 十分時間経過後に到達する自然電位 $E_{\mathrm{SP}^{\prime}}$ を測定し, 結 果を Table 5 にまとめて示した。併せて試験後の試験片 が金属光沢を維持していた場合を ○，そらでない場合を 


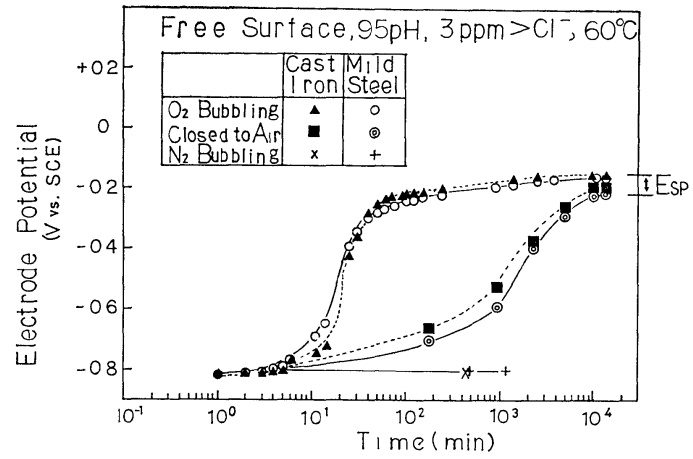

Fig. 2 Time variation of electrode potential for free surface specimen freely immersed in WG Solution A with pH 9.5. In aerated conditions, it attains $E_{\mathrm{SP}}$ of about $-0.2 \mathrm{~V}$ as spontaneous potential for steels wholly passivated in the environment.

Table 5 Spontaneous electrode potentials in V vs. SCE at room temperature for cast iron and mild steel freely immersed in aerated WG Solution $\mathrm{A}$ of various $\mathrm{pH}$ values corresponding to various contents of DEEA. The remarks $\bigcirc$ and $x$ denote passive and active states of steels, respectively.

\begin{tabular}{|c|c|c|c|c|c|c|c|c|}
\hline & \multicolumn{4}{|c|}{ Cast Iron } & \multicolumn{4}{|c|}{ Mild Steel } \\
\hline $\begin{array}{c}60^{\circ} \mathrm{C} \mathrm{pH} \\
\left(20^{\circ} \mathrm{C} \mathrm{pH}\right)\end{array}$ & $\begin{array}{l}\text { Close } \\
\text { Air }\end{array}$ & & $\mathrm{O}_{2}$ & & $\begin{array}{l}\text { Close } \\
\text { Air }\end{array}$ & & $\mathrm{O}_{2}$ & \\
\hline $10.6(11.0)$ & -0.16 & 0 & -0.16 & 0 & -0.29 & 0 & -0.26 & 0 \\
\hline $9.5(10.0)$ & -0.20 & 0 & -0.18 & 0 & -0.22 & $\mathrm{O}$ & -0.18 & 0 \\
\hline $8.9(9.5)$ & -0.21 & 0 & -0.12 & 0 & -0.18 & 0 & -0.15 & 0 \\
\hline $7.9(8.5)$ & -0.62 & $x$ & -0.55 & $x$ & -0.12 & $\mathrm{O}$ & -0.10 & 0 \\
\hline
\end{tabular}

\section{×で示した。}

鋳鉄試験片では, pH 7.9 の液において, $-0.62 \mathrm{~V}$ と 卑な電位を示し, 金属光沢も維持していない。その他の 8.9 以上の $\mathrm{pH}$ での金属光沢を維持している鋳鉄の自然 電位 $-0.21 \sim-0.12 \mathrm{~V}$ は上述の $-0.18 \mathrm{~V}$ と同様 $E_{\mathrm{SP}}$ で あるとしらる。一方軟鋼試験片は, $\mathrm{O}_{2}$ 通気, (通気を行 わない) 緩密閉の場合とも, pH 7.9〜10.6 に和いて金属 光沢を維持し, $E_{\mathrm{SP}}=-0.29 \sim-0.10 \mathrm{~V}$ を示している。

以上の結果から自己不動態化する最小の $\mathrm{pH}$ 值は, 鋳 鉄に和いて 7.9 8.9 の間にあり, 軟鋼に扔いては $\mathrm{pH}$ 7.9 以下であることがわかる。

2.9 の方法による自然電位と $\mathrm{pH}$ との測定結果を $60^{\circ} \mathrm{C}$ の $\mathrm{Fe}-\mathrm{H}_{2} \mathrm{O}$ 系 $E-\mathrm{pH}$ 図 ${ }^{6)}$ 上にプロットし, Fig. 3 に示した。 $\mathrm{pH}$ 変化の向さを矢印で示した。図中でこ で囲って示したプロットは Table 5 の $E_{\mathrm{SP}}$ 值である。

$\mathrm{pH} 8.9$ に打いて 2.9 の方法による自然電位, $E_{\mathrm{SP}}{ }^{\prime}$ は 上述の $E_{\mathrm{SP}}$ に一致し, $E_{\mathrm{SP}}$ 相当值として, 十分使用でき ることがわかる。

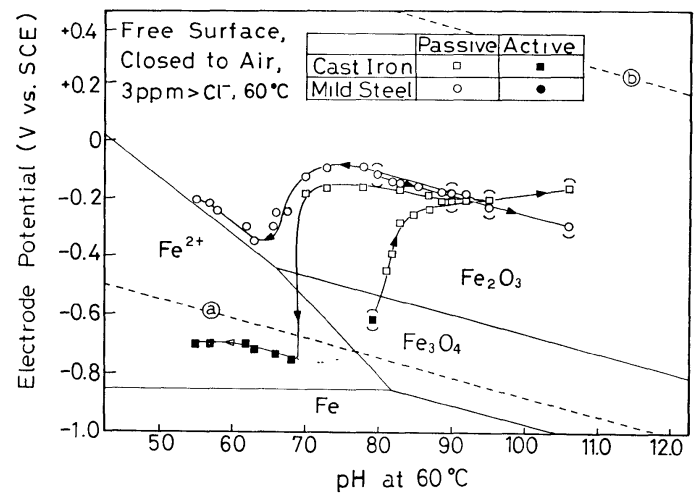

Fig. 3 Variation of electrode potential with $\mathrm{pH}$, with respect to $E$-pH diagram at $60^{\circ} \mathrm{C}$.

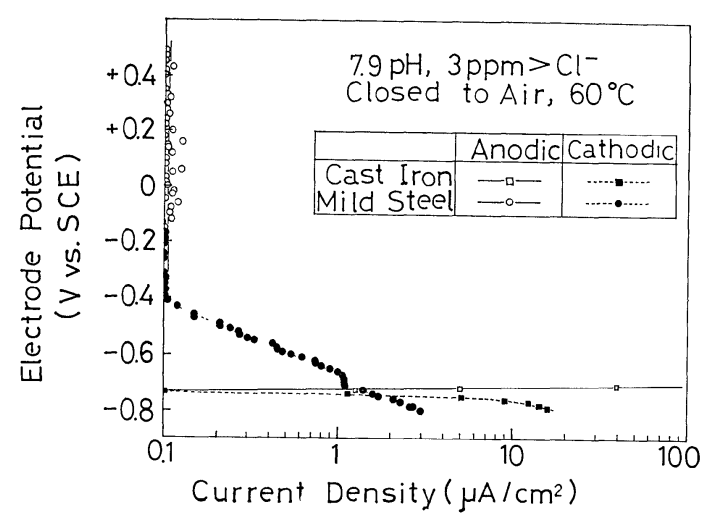

Fig. 4 Polarization curves for cast iron and mild steel in WG Solution A with pH 7.9 at $60^{\circ} \mathrm{C}$.

鋳鉄の自然電位は $\mathrm{pH} 7.9$ で $-0.62 \mathrm{~V}$ を示すが, $\mathrm{pH}$ を 8.3 にすると $50 \mathrm{mV} / \mathrm{h}$ 以上の速度で急激に貴化し $-0.25 \mathrm{~V}$ に達する。従って, 鋳鉄の場合には, 8.3 以上 のH 領域で自己不動態化が達成されることがわかる。 また自己不動態化がすでに達成されている $\mathrm{pH}$ 領域から $\mathrm{pH}$ を低下させると, $\mathrm{pH}$ が 7.0 で自然電位は $-0.17 \mathrm{~V}$ を示すが, $\mathrm{pH}$ 6.8で急激に $-0.72 \mathrm{~V}$ まで卑化し, $\mathrm{Fe}^{2+}$ が安定な腐食域に入ることがわかる。上述の結果より鋳 鉄の場合, $\mathrm{pH}$ の上昇過程で測定される脱不動態化 $\mathrm{pH}$, $\mathrm{pH}_{\mathrm{d}}$ は 8.3, また $\mathrm{pH}$ の低下過程で測定されるとれは 6.8 と求められる。一方軟鋼の自然電位は, $\mathrm{pH}$ が 7.0 から 6.8 に低下する過程に打いて鋳鉄と同様に早化するが, その程度は鋳鉄の場合ほど大さくはなく, かつ $\mathrm{Fe}^{2+}$ 安 定域には入らず, $\mathrm{Fe}_{2} \mathrm{O}_{3}$ 安定域内を $\mathrm{Fe}^{2+}$ との境界にそ ら挙動を pH 5.5 までとる。Fig. 4 に後述するように, この過程を通じて不動態に保たれるようである。

pH 7.9 での鋳鉄及び軟鋼の動電位分極曲線を Fig. 4 に示す。鋳鉄では, 貴方向への電位掃引に伴い, -0.73 
V vs. SCE でアノード分極域となり，-0.70Vでアノー ド電流が $50 \mu \mathrm{A} / \mathrm{cm}^{2}$ に達した。鋳鉄の場合, これらの腐 食域は Fig. 3, E-pH 図中, の $\mathrm{Fe}_{3} \mathrm{O}_{4}$ 域に相当し, ここ での $\mathrm{pH} 7.9$ は $\mathrm{pH}_{\mathrm{d}} \fallingdotseq 8.3$ より低いといら事実と矛盾し ない。

一方軟鋼では, Fig. 4 の分極曲線より，不動態域が $-0.15 \mathrm{~V}$ vs. SCE 以上の貴な電位域にあることがわか る。この電位域は Table 5 及び Fig. 3 でるとめた $E_{\mathrm{SP}}$ 值, それぞれ, -0.12 及び $-0.10 \mathrm{~V}$ ，に注涪一致し， Table 5 で述べた，金属光沢を保りという外観が不動態 状態を反映していることを示している。

Table 1 に示した Case 6 9 の鋳鉄の腐食事例の場 合, $\mathrm{WG}$ 液の $\mathrm{pH}$ 值は $60^{\circ} \mathrm{C}$ で $8.9 \sim 9.2$ 之, 新液の 9.5

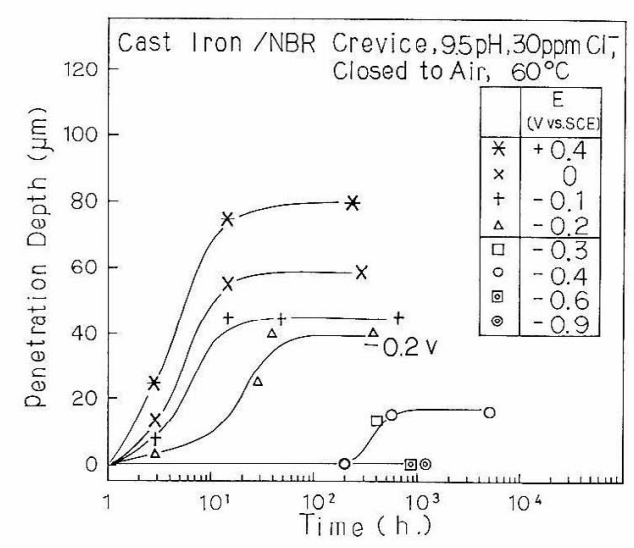

(a)

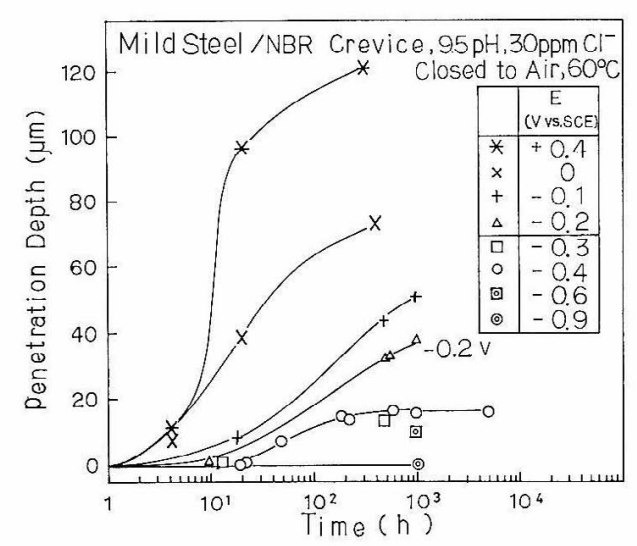

(b)

Fig. 5 (a), (b) Maximum penetration depths observed for creviced specimens of cast iron (a) and mild steel (b), kept under conditions of various potentials and times. Here exists critical potential, $V_{\mathrm{CREV}}$, of about $-0.25 \mathrm{~V}$ above which crevice corrosion continues to grow over $20 \mu \mathrm{m}$ in penetration depth.

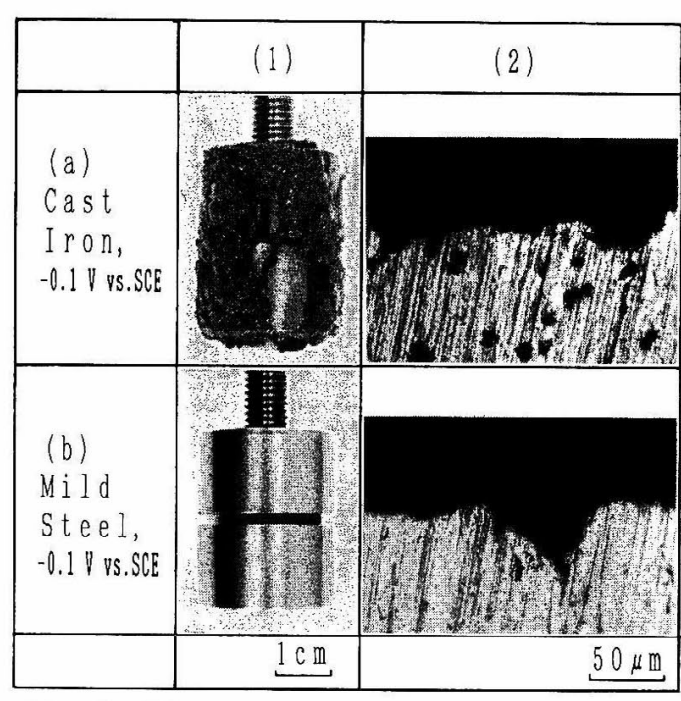

Fig. 6 Side view (1), and cross section of crevice corrosion (2) for metal/NBR-creviced specimen of cast iron (a) and mild steel (b) after immersion in WG Solution A of $30 \mathrm{ppm} \mathrm{Cl}^{-}$, and $\mathrm{pH} \mathrm{9.5,} \mathrm{for} 1000 \mathrm{~h}$, at potentials of $-0.1 \mathrm{~V}$.

より低下しているわのの, 上求めた $\mathrm{pH}_{\mathrm{d}} \fallingdotseq 8.3$ より高 い值に維持さ祅ていた。従って, Case 6〜9 の腐食が $\mathrm{pH}$ 值の低下が原因で起きたとは考完にくい。

\section{2 すきま腐食発生・成長挙動}

$\mathrm{Cl}^{-}$濃度を $30 \mathrm{ppm}$ に調整した緩密閉条件のWG 液 A

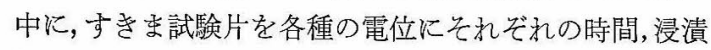
保持したあとの侵食樑さの測定結果を，鋳鉄及び軟鋼に ついて，艺れぞれFig. 5 (a) 及び Fig. 5 (b) と示す。また， $-0.1 \mathrm{~V} \ll 1000 \mathrm{~h}$ 保持後取り出した鋳鉄, 軟鋼試験片の 観察結果を Fig. 6 飞示す。図中の左写真 (1) は $-0.1 \mathrm{~V}$ 保持後の開放外観, 右写真 (2) はその腐食部分断面の光 学顕徽鏡写真である。Fig. 5 (a) 飞示した鋳鉄の場合に は, $-0.2 \mathrm{~V}$ 以上の貴な電位に保持すると，すきま腐食 は深さ力向に $20 \mu \mathrm{m}$ をこえて進行し，電位が貴であるほ ぞ進行速度が大きい。侵食が電位に応じたそれぞれの深 さに達した後は深さ方向へは進行しにくくなる。この 時, Fig. 6 上写真 (a) 飞示与上5に, 横方向に侵食が進行 し、すきま部を起点として大量の腐食生成物が発生する ことを観察した。・方， $-0.3 \sim-0.6 \mathrm{~V}$ の電位保持し た場合には，侵食深さは $20 \mu \mathrm{m}$ 以上には進行せず -0.4 $\mathrm{V}$ では 208 日 $=4992 \mathrm{~h}$ 後子侵食深さは $20 \mu \mathrm{m}$ 以下であ った。さらに卑な電位の $-0.9 \mathrm{~V}$ の場合には $1000 \mathrm{~h}$ 後 でもすきま腐食をはとんど認めなかった。なお， $-0.3 \mathrm{~V}$ 以下の卑な電位に保持した場合には貴な電位域でのよう な大量の腐食生成物の生成も認められなかった。

Fig. 5 (b) に示した軟鋼の場合にも鋳鉄と同樣に 
$-0.2 \mathrm{~V}$ 以上の貴な電位に保持した場合には，侵食速度 が大きく，24h で 20 100 $\mu \mathrm{m}$ 達する挙動のあること がわかる。しかし鋳鉄とは異なり，電位に応じた一定深さ 以上には進行しにくい傾向はなく，侵食はFig. 6 下写真 (b) に示すようにもっぱら深さ方向に進行し, 横方向一 の侵食, 及びすきま部を起点とした大量の腐食生成物生 成は観察されなかった。なお， $-0.3 \mathrm{~V}$ 以下の卑な電位 飞保持した場合, 侵食は $20 \mu \mathrm{m}$ 以上には進行しないこ と, 及び大量の腐食生成物生成が認められないことは, 鋳鉄と同様であった。

以上の鋳鉄, 軟鋼いずれも, 侵食深さが $20 \mu \mathrm{m}$ を臨界 として，すきま腐食が進行する貴な電位域が 観察され た。この進行性すきま腐食発生下限界電位， $V_{\mathrm{CREV}}$. は Fig. 5 に示した $30 \mathrm{ppm} \mathrm{Cl}^{-}$を含む液において約 -0.25 $\mathrm{V}$ とみなし得る。

また, Fig. 2 でもとめた $E_{\mathrm{SP}}$ 值以下の卑な電位 $-0.4 \mathrm{~V}$ 飞保持した場合の, 非進行性すき腐食域に打 いては， $\mathrm{N}_{2}$ 脱気した場合は，上述の脱気しない緩密閉 の場合に比べ腐食速度が低下寸ることが認められた。こ の非進行性すきま腐食が緒言に述べた，通常に認められ るが進行性ではないすきま腐食，飞対応するものと考兄 られる。

\section{3 すきま再不動態化電位, $\boldsymbol{E}_{\mathrm{R}, \mathrm{CREV}}$ の測定}

$E_{\mathrm{R}, \mathrm{CREV}}$ と, $E_{\mathrm{R}, \mathrm{CREV}}^{*}$ 測定後の試験片の侵食深さとの 関係を Fig. 7 亿示す。鋳鉄 $($ 国), 軟鋼 $(○)$ とも侵食深さ $20 \mu \mathrm{m}$ 臨界值が存在し，この臨界值より浅いすきま腐 食についてその再不動態化電位, $E_{\mathrm{R}, \mathrm{CREV}}^{*}$ は, 鋳鉄で $-0.24 \sim-0.26 \mathrm{~V}$, 軟鋼で $-0.22 \sim-0.24 \mathrm{~V}$ と, 侵食深

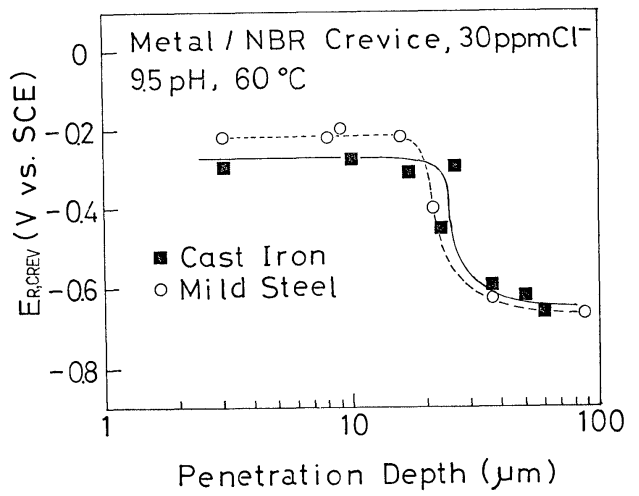

Fig. 7 Relationship between repassivation potential for crevice corrosion, $E_{\mathrm{R}, \mathrm{CREv}}$, and maximum penetration depth as an extent of preceding growth of crevice corrosion. Here exists a critical penetration depth, of about $20 \mu \mathrm{m}$, shallower than witch the value of $E_{\mathrm{R}, \mathrm{CREV}}, E_{\mathrm{R}, \mathrm{CREV}}^{*}$, does not depend on maximum penetration depth.
さ，測定方法に依存しない一定值として求められる。こ の值は Fig. 5 で求めた，すき否食発生の下限界電位, $V_{\mathrm{CREV}} \fallingdotseq-0.25 \mathrm{~V}$ に注ぼ一致する。したがって $20 \mu \mathrm{m}$

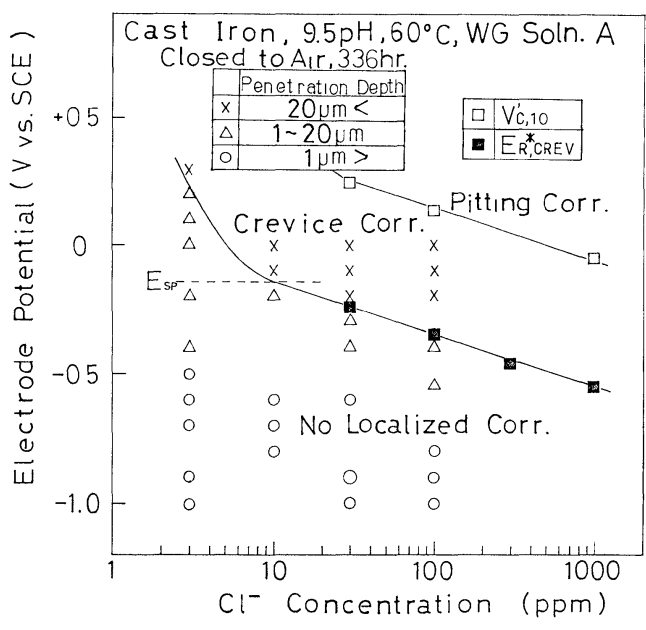

( a )

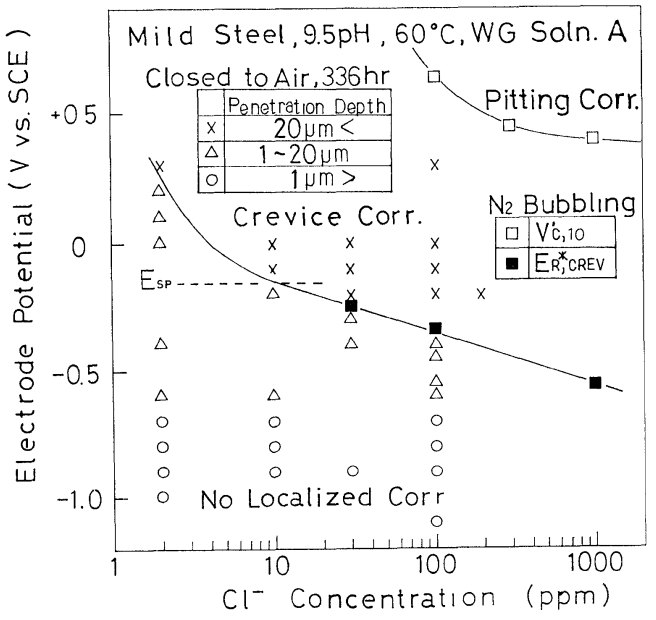

(b)

Fig. 8 Corrosion resistance regions for WG Solution A to cast iron (a) and to mild steel (b) in terms of electrode potential and $\mathrm{Cl}^{-}$concentration. $(\times)$, $(\triangle)$ and $(\bigcirc)$ show the extents of penetration as denoted in the figure after potentiostatic crevice corrosion test for $336 \mathrm{~h}$. Critical potential, $V_{\mathrm{CREv}}$, as the boundary line between $(x)$ and $(\triangle)$ regions coincides with the value of $E_{R, C R E V}^{*}$ shown by (匹). Comparison of these critical potentials with $E_{\mathrm{SP}}$, electrode potential of steels passivated in the solution, which is $-0.1 \sim-0.2 \mathrm{~V}$, predicts occurrence of crevice corrosion only in solutions containing $\mathrm{Cl}^{-}$more than $10 \mathrm{ppm}$. 
より浅い侵食は，仮に生成しても $E_{R, \mathrm{CREV}}^{*} \fallingdotseq-0.25$ $\mathrm{V}$ 以下の卑な電位では必ず再不動態化してしまう。この 意味で両者の一致は, 求めた $\mathrm{V}_{\mathrm{CREV}}$ 值の信頼性を保証 している。

\section{4 腐食領域図}

WG 液 $\mathrm{A}$ 中の塩化物を種々の濃度没設定し, $V^{\prime}{ }_{\mathrm{C}, 10}$ と $E_{\mathrm{R}, \mathrm{CREV}}^{*}$ とを, 鋳鉄について測定した結果を Fig. 8 (a) に, 軟鋼の結果を Fig. 8 (b) と示す。また，すきま試 験片の定電位浸漬試験を 2 週間 $=336 \mathrm{~h}$. 実施した後の結 果 ( $\times: 20 \mu \mathrm{m}$ 以上の侵食, $\Delta: 20 \mu \mathrm{m}$ 未満の侵食, $\bigcirc:$ 侵 食なし）もあわせ示した。Fig. 8 (a) の鋳鉄, Fig. 8 (b) の軟鋼とも, $\mathrm{Cl}^{-}$濃度が 30 100 ppm では, $\times / \triangle$ の境界

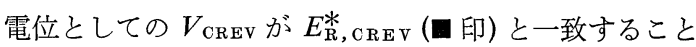
がわかる。

Table 5 で求めた自然電位 $E_{\mathrm{SP}}$ と Table 1 亿示した 実際事例に括ける鋳鉄製タンク壁の自然電位とは, -0.1 $\sim-0.2 \mathrm{~V}$ の範囲にあった。これらの平均值, $-0.15 \mathrm{~V}$ を図中に $\mathrm{E}_{\mathrm{SP}}$ として記入すると，いずれに拈いても， $\mathrm{Cl}^{-}$濃度約 $10 \mathrm{ppm}$ を境として, 高濃度側では $E_{\mathrm{R}, \mathrm{CREV}}^{*}$ $\leqq E_{\mathrm{SP}}$ ，低濃度側で $E_{\mathrm{SP}} \leqq E_{\mathrm{R}, \mathrm{OREV}}^{*}$ となること，すなわ ち WG 液 $\mathrm{A} の \mathrm{Cl}^{-}$濃度を約 $10 \mathrm{ppm}$ 以下に管理すれ ば，耐食域に入ることがわかる。Table 1 に示した腐食 事例の WG 液は, $\mathrm{Cl}^{-}$濃度として $16 \sim 32 \mathrm{ppm}$ が検出 されており，上述の $E_{\mathrm{SP}}$ 值では，進行性すきま腐食域 (×) に入ることが予測される。すなわち Table 1 の事例 は $\mathrm{Cl}^{-}$によるすきま腐食と判定しうる。使用中に $\mathrm{Cl}^{-}$が 増加した原因は, 例兄ば水道水, 工業用水などの塩化物 含有水を補給したのではないかと考兄られる。

また， $E_{\mathrm{SP}}$ が同じ值をとると仮定する限り，鋳鉄及び 軟鋼とも $\mathrm{Cl}^{-}$濃度が調查上限の $1000 \mathrm{ppm}$ の液中に括い ても， $E_{\mathrm{SP}}$ が $V_{\mathrm{C}, 10}^{\prime}$ を兄ない，すなわち孔食域には入 らないことも, 経験された腐食形態がすきま腐食に限ら れる事実と対応する。

\section{4. まとめ}

弱アルカリ性水溶液に調整され,グリコール類を主成 分とする, 市販 WG 作動液中に打兴鉄の脱不動態を, $\mathrm{pH}$ と $\mathrm{Cl}^{-}$条件に扣いて調査し，をた腐食事例の原因を 検討した。その結果, 次のことが明らかとなった。
（1）実験に使用した WG 液 A と抢沙脱不動態化 $\mathrm{pH}, \mathrm{pH}_{\mathrm{d}}$ ，は鋳鉄で約 8.3 , 軟鋼で 7.9 以下，と測定され た。WG 使用液の $\mathrm{pH}$ 值をこの $\mathrm{pH}_{\mathrm{d}}$ より高い值に管理 すれば, 通常の使用条件で期待される程度の大気中酸素 の効果によって，両者とも自己不動態化することがわか った。

（2）すきま腐食の予測に，再不動態化電位概念が適 用できることを確認した。侵食深さが $20 \mu \mathrm{m}$ をこえない 浅いすきま腐食についてその再不動態化電位， $E_{R, \mathrm{CRE} \mathrm{V}}^{*}$ は,

(1) 成長度合いに依存しない一定値として求められ る,

（2)侵食深さが $20 \mu \mathrm{m}$ をこ党る進行性すきま腐食発 生の下限界電位, $V_{\mathrm{CREV}}$, に一致する,

(3) 環境中不動態化鋼の自然電位, $E_{\mathrm{SP}}$ との比較によ り，すきま腐食生起を予測することができる。

（3）（2）-(3) 飞基づいて, 通常の使用環境に执いてす きま腐食を防止するには, $\mathrm{Cl}^{-}$濃度を約 $10 \mathrm{ppm}$ 以下に 管理すれば良いことが予測される。

（4）腐食事例の WG 使用液は, pH 值は WG 液 A $の \mathrm{pH}_{\mathrm{d}}$ 值以上飞管理されていたが, $\mathrm{Cl}^{-}$濃度が $10 \mathrm{ppm}$ をこえて上昇したため，進行性すきを腐食を起こしたと 推定された。

（5）鋳鉄, 軟鋼とも $\mathrm{Cl}^{-}$濃度が $1000 \mathrm{ppm}$ 以下では 孔食を起こさない。この予測は懸念される腐食形態がす きま腐食に限られている事実に矛盾しない。

終わりに，本研究の遂行にあたり， $E_{\mathrm{R}}$ 測定プログラ ムととれを装置へ組久込む方法について御指導, 御助力 を賜わりました東京大学工学部金属材料学科, 篠原 正 博士に深く感謝の意を表します。

(Received April 14, 1988)

\section{文献}

1) M. Pourbaix: Corrosion-NACE, 26, 431 (1970).

2）辻川茂男, 久松敬弘：防食技術, 29, 37 (1980).

3）辻川茂男, 柏瀬正晴, 玉置克臣，久松敬弘：防食 技術, 30, 62 (1981).

4）壱岐史章, 辻川茂男：鉄々鋼, 72, 292 (1986).

5）篠原 正, 辻川茂男, 久松敬弘, 高野太刀雄, 岡 村弘之：防食技術, 31, 650 (1982).

6) H. E. Townsend, Jr.: Corr. Sci., 10, 343 (1970). 